\title{
Twenty-five years after
}

\author{
Gerald P. O'Driscoll, Jr. ${ }^{1}$
}

It never occurred to me after finishing The Economics of Time and Ignorance that I would be sitting on a panel a quarter-century later discussing the book. Indeed, when Mario contacted me to let me know of its reissuance ten years after the initial publication, it was a pleasant surprise. In preparing for this session, I reread Mario's Introduction to the second edition and it motivated me to reconsider the influences on us - or at least me - in writing the book.

The influence of having both Israel Kirzner and Ludwig Lachmann as colleagues has been well-told, including in Mario's Introduction. I want to go back further, to Hayek. Over the years, I have come to view Hayek's essay "Price Expectations, Monetary Disturbances and Malinvestments," to be of overriding importance. I refer to it as the Copenhagen Lecture because it evolved from a 1933 lecture in Copenhagen and because of its unwieldy title. So Hayek made the substance of the essay's argument in 1933 and saw the essay published in German (later in French) in 1935. It did not appear in English until the end of the decade (Hayek 1939).

The original lecture's delivery date coincides roughly with the publication of Hayek's edited volume, Collectivist Economic Planning. It predates the 1937 essay, "Economics and Knowledge" (1937). He footnotes the 1933 lecture in that essay (at least in the version reprinted in Individualism and Economic Order). ${ }^{2}$ Hayek's 1937 essay is credited with the first statement of the proposition that equilibrium means that individuals have correct foresight and that equilibrium is plan coordination. But that conception is central to the argument of the Copenhagen Lecture. In the lecture, he insists on the necessity of making assumptions about what expectations of the future individuals possess in order to construct a concept of equilibrium in time.

The assumptions of this kind which are implied in the concept of equilibrium are essentially that everybody foresees the future correctly and that this foresight includes not only the changes in the objective data but also the behavior of all other people with whom he expects to perform economic transactions.

(Hayek 1939: 139-40)

DOI: $10.4324 / 9781315776736-17$ 
The Copenhagen Lecture unifies Hayek's work on the informational content of prices; the differentiation between individual and societal concepts of equilibrium; the institutional comparison of resource allocation in centrally planned and individually planned economies; and the problems of foresight and intertemporal resource allocation in the face of monetary disturbances.

The Copenhagen Lecture demonstrates that Hayek was simultaneously working out similar theoretical problems across diverse areas of economics, which we would today label micro, money-macro and comparative institutions. While he may later have forgotten that, there is textual evidence he was conscious of the linkages of these problems at the time. More than anything, it shows the unity of his work. ${ }^{4}$

I certainly did not neglect the lecture when writing my dissertation on Hayek, expanded and published as Economics as a Coordination Problem (O’Driscoll 1977). I devoted considerable space to it. But I now realize that the problems Hayek focused on in the lecture and later in "Economics and Knowledge" were central to what I'll call the NYU controversies and the lingering debates over our book.

Hayek began the Copenhagen Lecture by observing that "The most characteristic feature of the work of our generation of economists is probably the general endeavor to apply the methods and results of the pure theory of equilibrium to the elucidation of more complicated 'dynamic' phenomena" (Hayek 1939: 135). It is instructive to note a change of mind by the mid-1930s on how the task should be approached. He stated that he once thought cycle theory should be "organically superimposed" on the static theory of equilibrium. Later, he came to believe that general theory should be developed so as to be applicable to the analysis of economic fluctuations (Hayek 1939: 13738). In other words, pure theory should be developed with time as an essential part and the equilibrium concept should be one of coordination across time periods. That was a major goal of our book.

For Hayek, "the main difficulty" with received economic theory "is its complete abstraction from time" (Hayek 1939: 139). He outlines the approach he would take, which appears in the passage already quoted. It is not clear that the radical nature of his reformulation of economic theory was understood, however, much less accepted, even by Austrians. Hayek returned to the conception of social phenomena underlying that concept in his work on political philosophy and law. The economics profession at large, after a detour through the Keynesian Revolution, had arrived at its own solution: Arrow-Debreu and Walrasian general equilibrium theory. But Austrian economists had not advanced Hayek's program. The question is why?

In his Introduction to the second edition of our book, Mario Rizzo discusses in almost clinical fashion the protracted debate over the entrepreneur. The debate is central to the issue at hand. Hayek understood that answering the question of "what determines the expectations of entrepreneurs" was pivotal. For a long time, Kirzner maintained that all entrepreneurial action is equilibrating. Considerations of the passage of time did not change his conclusion. 
As Rizzo noted: "Such a view is plausible because the adjusting changes have no impact on the data to which they are adjusting" (O'Driscoll and Rizzo 1996: xviii). Contrast Kirzner's position with Hayek's opposing one.

Even then, and certainly in retrospect, it is amazing that Kirzner was maintaining his view into the 1980s. In the 1937 and 1939 papers, Hayek distinguished between the equilibrium of an individual and the vastly more complex concept of an overall market or societal equilibrium (Caldwell 2004: 206-09). Hayek (1939: 139) saw that equilibrium (plan coordination) has meaning either for "an isolated person" or "a centrally directed communist system." But he went on to write that "it is much less clear" when we apply the concept to a competitive society. Because then we face the problem of individual responses to the actions of their fellow individuals that "necessarily take place in time, and which can be represented as timeless equilibrium relationship only by means of unrealistic special constructions."

Mario and I began where Hayek left off. There was great resistance in some quarters to our reformulation of Austrian economics. I think it is fair to say that The Economics of Time and Ignorance helped break that resistance and, more importantly, opened possibilities for others to advance Hayek's program. In our book, we advanced a concept of real time in which surprise and innovation are inherent features of markets. Surprise and innovation are endogenous outcomes of actions taking place in time. The data change as a consequence of entrepreneurial individuals adapting to the data and to the prior adaptations of their fellow actors. We thus advanced Hayek's agenda. $^{5}$

I suspect that Kirzner's portrayal of the entrepreneur as an inherently equilibrating force was really a defense against what he saw as an attack on the Misesian program. Kirzner mounted the battlements to protect the a priori core of that program. In his mind, a breach of the outer defenses threatened the core. The issue was Hayek's call in the 1937 article for economics to be "an empirical science," which has been interpreted by many as an attack on Misesian apriorism.

I am aware that, if I offer this hypothesis, I solve the mystery of Kirznerian intransigence but not the mystery of Misesian indifference. As Caldwell (2004: 221) explains (quoting Hayek), Mises took Hayek's criticism of apriorism in his 1937 paper "more good naturedly than in most other instances." Mises was a notoriously prickly individual who took offense to the point of breaking with both Haberler and Machlup for years. Yet on this seemingly fundamental issue, Mises took no offense.

Mises sharply distinguished between the construct or model of the evenly rotating economy and actual, real-world markets. "The essence of this imaginary construction is the elimination of the lapse of time and the perpetual change in the market phenomena" (von Mises 1966: 247). And von Mises (1966: 247) was emphatic that "there is never such a thing as an evenly rotating economic system." Where Hayek and others saw conflict, perhaps Mises saw fulfillment of his own vision. 
Pete Boettke has suggested that the best way to read Hayek is as a Misesian, and the best way to read Mises is as a Hayekian. The episode, as described by Caldwell, may be an example of why Boettke's approach may be fruitful.

Hayek called for moving beyond the Pure Logic of Choice to construct an economics in time. That surely was Mises' goal as well, as clarified in his later work. As far as the economics of time is concerned, Hayek and Mises were in agreement. Time changes everything in the analysis, and everything changes with the passage of time. The Austrian generation after Mises and Hayek were not always so clear. Lachmann is a notable exception.

Our book did start a renewal in Austrian economics, and advanced both the Hayekian and Misesian conception of subjectivist economics. The book's success must be measured by whether that renewal supports a self-sustaining learning and growth process. Boehm (2012) offers a re-examination that is at once fair and also critical in parts (Boehm 2012: 4). He credits the book with stimulating research in Austrian economics, but questions whether we made an impact on the mainstream.

I do not want to directly respond for our book, but address the broader issue of the impact of Austrian economics on the mainstream. In some ways, Austrian economics is part of the mainstream and in other ways it is not. In Congressional testimony, Henry Manne (2012: 21) credited Mises and Hayek for their criticism of central planning and observed that "with small modifications" it could be applied to the modern regulatory state. He also described Hayek's article on "The Use of Knowledge in Society" as "one of the most famous and influential articles in all of economic history." I am confident that far more economists today know Hayek's argument than realize its origin.

Manne also provides an account of the seminal influence of Public Choice Theory on regulation. Among other insights, Public Choice Theory predicts that regulatory agencies will be subject to capture and end up promoting the interests of the regulated industry over the public interest. Manne (2012: 21) observes that this criticism of regulatory agencies and others have "become standard fare in political theory." And what has the influence been on regulatory practice? Zero.

None of the works Manne cites either in Public Choice Theory or in Austrian economics employed high-brow modeling. Yet they gained acceptance in the profession. Despite widespread professional acceptance, however, ideas can have no impact on policy. I think most economists would like to have felt that their ideas had some practical impact.

Since 2007, I have written numerous articles, commentaries and papers on the financial crisis. Most of these embodied what I will call applied analysis from The Economics of Time and Ignorance. I have received recognition for my insights from a broad public audience and also from mainstream economists. I have also watched issues that I was the first or among the first to raise (crony capitalism in America) and at least one phrase I coined (casino banking) entered into the daily lexicon. One prefers credit, but there is satisfaction to helping change the terms of a debate. To paraphrase Ronald Reagan, there 
is no amount of good you can't accomplish if you don't insist on getting credit. I take this to be what Boehm (2012: 13) meant when he raised the possibility of appealing to a wider audience. I am personally satisfied with the impact of our book after 25 years, if only because of its impact on discussions of public policy issues.

\section{Notes}

1 I wish to thank David Harper for organizing the panel at the 2011 Southern Economic Association meetings.

2 It is apparent that the footnote was at least updated for the book because Hayek cites the English publication of the Copenhagen Lecture, which was later than the essay's original publication.

3 At this point, Hayek inserted a footnote to "Economics and Knowledge," describing it as a further elaboration and "partly revised" discussion of the argument of the Copenhagen Lecture.

4 The unity of Hayek's work undermines the argument of Caldwell (2004) and others that Hayek's 1937 essay (1937) represented a "transformation in Hayek's thinking." O'Driscoll (2004) deals in detail with that claim.

5 This telling of the story clarifies why questions about originality are difficult to answer. The underlying idea was Hayek's, but had not been fully absorbed in subsequent research. We rediscovered and advanced it. In any case, truthfulness trumps originality.

\section{References}

Boehm, S. (2012). Reflections on The economics of time and ignorance coming of age. Review of Austrian Economics, 26 (1), 7-15.

Caldwell, B. (2004). Hayek's challenge: an intellectual biography of F. A. Hayek. Chicago and London: University of Chicago Press.

Hayek, F. A. (ed.) (1935) Collectivist economic planning: critical studies on the possibilities of socialism. London: George Routledge and Sons.

Hayek, F. A. (1937). Economics and knowledge. Economica (February), 33-54. Reprinted in Hayek (1948).

Hayek, F. A. (1939 [1970]). Profits, interest and investment. New York: Augustus M. Kelley.

Hayek, F. A. (1948). Individualism and economic order. Chicago: University of Chicago Press.

Manne, H. (2012). Economics and financial regulation. Regulation, 35 (Summer), $20-25$.

O’Driscoll, G. P., Jr. (1977). Economics as a coordination problem. Kansas City: Sheed, Andrews and McMeel.

O'Driscoll, G. P., Jr. (2004). The puzzle of Hayek. Independent Review, IX (Fall), 271-281.

O’Driscoll, G. P., Jr. and Rizzo, M. J. (1996). The economics of time and ignorance. London and New York: Routledge.

von Mises, L. (1966). Human action: a treatise on economics. (3rd ed.) Chicago: Henry Regnery. 